\title{
The Influence of Medialization to Legal Discourse Concerning Context, Media and Social Power
}

\begin{abstract}
Annikki Koskensalo
University of Turku, Turku, Finland

Medialization has become like digitalization, rationalization, dynamization, globalization, pluralization, hybridization, and differentialization and is one of the buzzwords of modern Western industrialized societies, which are all together essentially responsible for structural change in communication. Medialization means the adaption of producers to media logics, media formats, and media routines \& workflows. There are consequently and logically influences because of the dynamic process of medialization to legal discourse and genres, law, media, and social power. It has to be discussed if the logics, data formats, and routines \& workflows of new media and information and communication technologies (ICTs) like social media are creating also a new generation of genres and novel form of legal discourses. Also, if social media will replace or complete old classic media (law of Riepl), the question of the relevance of law concerning new \& social media has to be answered in close future. Lastly, if to the fore of social power, these new novel resources are actually framing for problem-based inquiries in law. There are big chances but also serious risks in cyberworld, their realities, and dangers. There actually exists an urgent call of action to theory building, development of methodologies, and empirical research.
\end{abstract}

Keywords: (self-) medialization, digitalization, legal discourse, context, media, social power

\section{Introduction}

Digitalization is changing the system of law. The science of law (jurisprudence) starts just now to ponder on this problem (Boehme-Neßler, 2008). The theory of fuzzy law postulates that law is changing fundamentally in a digitalized environment (p. 74). Because of this theory, the meaning of law as an instrument of social regulation is relativizing itself significantly (pp. 513-515). Law and digitalization examines the tension between disruption and regulation. Legal technology is shifting the boundaries of law and redefining how legal services are rendered. The first step towards digitalization of legal services done right is to define the needs and perspectives invested in law and technology (Koulu, Kallio, \& Hakkarainen, 2017, pp. 1, 16). But this surely very interesting relation between law and digitalization should not be the top subject of this article. The main focus and perspective will be the special connections between digitalization and (self-) medialization and the transformation of law because of medialization and digitalization (in analogy to Wimmer, 2017, pp. 245-247). In this context, medialization as an all-embracing meta-process is defined as mediation and interpenetration through and by media of everyday's life.

Annikki Koskensalo, Ph. D., professor, Institute of Foreign Languages Teaching \& Learning Research, University of Turku, Turku, Finland. 
In this process of transformation, there are together with medialization-other social all-embracing sub-processes, like digitalization (Lindenberg, 2018), individualization, globalization, and commercialization (p. 245). Mediatization can also be understood together with individualization, commercialization, and globalization as one of the meta-processes characterizing modern times (Schwarzenegger, 2010, p. 1). Nowadays medialization is linked together with digitalization or in analogy they are mutually dependent, because their contents and forms are interdependent. It seems to be clear that the technology of digital non-time-based architectures of knowledge is changing not only the pre-conditions of production and distribution of audio-visual media but also their contents (Lipp, 2015, p. 47). Any kind of function and acceptance of processes of mediatization and change of media (Schröder, 2018, pp. 13-34); (genuine) media revolutions (Schüttpelz, 2017, p. 150; Jaekel, 2017, pp. 8-29; Walach, 2018, pp. 79-98) is constituted of institutionalization which can be partly before or after these processes and change. This task has to be done mainly by the system of law. Therefore, all social processes of juridization of massmedia have to be especially studied and reflected. So, medialization cannot be thought respectively realized without juridification of media (Ziemann, 2018, pp. 67-68). After this short introduction to the structure of this article: In Part 1, there will be the concepts of digitalization (including digital transformation, revolution, and communication) and mediatization defined and described. In Part 2, there will be discussed the connections between these two concepts with a special focus to law, legal discourse, context, media, and social power. In Part 3, a small thesis-list will be presented which hopefully provokes some questions and critical reactions in the scientific community.

\section{Definition and Description of Digitalization and Medialization}

The academic discussion surrounding digitalization has been described as problematic as no clear definition of the phenomena has been previously developed. A common misconception is that digitalization essentially means the usage of more IT, in order to enable and take advantage of digital technology and data. This early definition, however, has largely been replaced by the below definition, now linked to holistic views on business and social change, horizontal organizational and business development, as well as IT.

\section{Digitalization}

Digitalization is defined as the process of converting information into a digital also computer-readable format, in which information (Völz, 2017) is organized into bits. Or in other words: Digitization is a sub-process of a much larger technological progress: digitization (the conversion), digitalization (the process), and the digital transformation (the effect) that are collectively accelerating the global and societal transformation process (Pispers, Rode, \& Fischer, 2018, pp. 11-39). In political, business, trade, industry, and media discourses, digitization is defined as the conversion of analog information into digital forms, like numeric and binary format (Lewrick, 2018; Baetzgen, 2017). Digitizing is technically explained as the representation of signals, images, sounds, and objects by generating a series of numbers, expressed as a discrete value. The majority of sectors and industries in media, banking and finance, telecoms, medtech, and health care have been strongly affected by this conversion of information. The result of this process is the representation of a signal (usually an analog one), document, object, or image by generating a series of numbers that describe a discrete set of its points or samples. The result of these representations is called digital representation or more specifically digital image, for the object, and digital form, for the signal. Digitized data is in the form of binary numbers, which facilitate 
computer-processing and other operations. But digitized simply means strictly spoken, the conversion of analog source material into a numerical format. The decimal or any other number system can be used instead. McQuail (2000, pp. 16-34) considered digitalization of crucial importance to data processing, storage, and transmission, because it allows information of all kinds in all formats to be carried with the same efficiency and also intermingled. It is also evident that by means of ICTs (information communication technologies) searching for information and decision-making will be simplified. Procedures of standardization are influencing this trend (Meisner, 2017, pp. 7, 33-35). Digital data theoretically can be propagated indefinitely with absolutely no degradation. Digitalization is the actual process of the technologically-induced change (Khan, 2016, pp. 6, 17) within a majority of sectors and industries in media, banking and finance (Hierl, 2017), telecoms, medtech, and health care. This process has enabled much of the phenomena today known as big data (Reichert, 2014; in relation with Big Divide, Rauschnick, 2017, p. 4), Internet of Things, industrial Internet, Industry 4.0, machine to machine communication, blockchain (Drescher, 2017), cryptocurrencies, cyberwar (Rid, 2018), etc.

\section{Digital Transformation}

Digital transformation is described as the total and overall societal effect of digitalization. Digitization has enabled the process of digitalization, which resulted in stronger opportunities to transform and change existing business models, consumption patterns, socio-economic structures, legal and policy measures, organizational patterns, cultural barriers, etc. Digitization (the conversion), digitalization (the process), and the digital transformation (the effect) therefore accelerate and illuminate the already existing and ongoing horizontal and global processes of change in society. This transformation (Oswald \& Krcmar, 2018, pp. 5-98) - synonym with Digital Change (N. N., 2017) - an be interpreted as a complex interaction between a socio-cultural and digital-technological level (medialization). Concerning this interaction, there can be identified four technological push factors: 1. datafication and digitalization; 2. networking and interaction; 3. sensorization and world surveying; and 4. algorithmization (Lehner, 2018; change of the public structure, Hagen, Wieland, \& In der Au, 2017, p. 127; social world comp, Lenzen, 2018, p.161) and machine-learning (Gapski, 2017, p. 1).

\section{Digital Revolution}

The Digital Revolution is the shift from mechanical and analogue electronic technology to digital electronics. This revolution began anywhere from the late 1950s to the late 1970s with the adoption and proliferation of digital computers and digital record keeping and continues to the present day (Schoenherr, 2004). This term also refers implicitly to the sweeping changes brought about by digital computing and communication technology during (and after) the latter half of the 20th century (Techtarget, 2014, pp. 1-2). Analogous to the Agricultural and Industrial Revolution, the Digital Revolution marked the beginning of the Information Age. Central to this revolution is the mass production and widespread use of digital logic circuits, and its derived technologies, including the computer, digital cellular phone, and the Internet (Debjani, 2014, p. 107). These technological innovations have transformed traditional production and business techniques (Bojanova, 2014, $\mathrm{p}$. 8). The notion of the digital revolution is part of the Schumpeterian theory of socio-economic evolution. It consists of an incessant process of creative destruction that modernizes the modus operandi of society as a whole, including its economic, social, cultural, and political organization (Schumpeter, 1939; Freeman \& Louçã, 2002). While there have been huge benefits to society from the digital revolution, especially in terms of the accessibility 
of information, there are a number of concerns. Expanded powers of communication and information-sharing, increased capabilities for existing technologies, and the advent of new technology brought with it many potential opportunities for exploitation. The Digital Revolution helped usher in a new age of mass surveillance, generating a range of new civil and human rights issues. Reliability of data became an issue as information could easily be replicated, but not easily verified. This revolution made it possible to store and track facts, articles, statistics, as well as minutiae hitherto unfeasible.

From the perspective of the historian, a large part of human history is known through physical objects from the past that have been found or preserved, particularly in written documents. Digital records are to create but also to delete and modify easily. Changes in storage formats can make recovery of data difficult or nearly impossible, as can the storage of information on obsolete media for which reproduction equipment is unavailable, and even identifying what such data is and whether it is of interest can be near impossible if it is no longer easily readable, or if there is a large number of such files to identify. Information passed off as authentic research or study must be scrutinized and verified.

\section{Digital Communication}

Digital communication (DC) is defined as communication with the assistance of digital media (Grimm \& Delfmann, 2017, p. 21; Finnemann, 2011, pp. 83, 67; Keyling, 2017, p. 44). DC deals with the interplay of information data organization and ability of textual expression of human language in contextual surroundings. In this case, the relation between syntax and semantics will be researched. The main research question will be here: Can the textual expression be determined by syntactic rules completely? With the consequence that human communication can be digitalized and completely automatized. The answer of this question: No! On the other hand will be described where the interface between human communicators and machine to machine-communication will be and how both parts, like digital communication, technical support, and aims of textual expressions play together. The theoretical foundation of this object will be constituted by three models of communication: philosophy of language (theory of speech acts with starting point of intentional action, algorithms), communication science like stimulus-response-model and information science like the model of entropy (Shannon), and layers-model (Drescher, 2017, pp. 23-27) of the Internet (Finnemann, 2011, pp. 83-84). Algorithms are a special form of plans in order to calculate mathematical functions. They have all together the same typical basic components: sequence, parallel size, conditions-controlled ramifications, loop, and outsourcing. A very special form of condictions-controlled outsourcing is recursion in which the algorithm calls up himself. Algorithms constitute the syntax of functions describing their realization step by step. The functions constitute the semantics of algorithms giving meaning to the process of calculation. There is one problem: All algorithms have a special meaning and are defining one function. Not every expression can be expressed by algorithms (p. 49). Three philosophical traditions like language as a projection apparatus of the world, language as an instrument of collective action and language as a model of concept modelling have the same essential result: That the static syntax of language is still incomplete. The mathematical incompleteness (Gödel) and stop-problem of Turing have demonstrated that the complete description of the world by ideal language (e.g., Tractatus of Wittgenstein, 1922) has failed. In actual perspective, language is influencing by interaction like language as a play of language (Wittgenstein, 1953) and language as action (speech acts). The Semantic Web is 
developing methods and instruments in order to express semantical relations syntactically and process them partly automatically (p. 93). DC as a complexe together with information transfer, selection and construction is substantiated theoretically by models like technical-transfer (Shannon) (p. 147), bi-directional exchange with socio-cultural embedding (Prakke), reflexivity (Merten), which means what in which channel to whom with which effect (Lasswell), change of communication (Vowe et al.), feedback of mass communication (Westley/McLean) and Supply Chain Management. In the center of DC-interest, there are the relations between speech and counter-speech (protocols), forms of expression and meaning, understanding, influence, and informational support through computer programs and nets (pp. 120-121). Concerning a complete definition of digital data, there are four aspects important: 1. logical structure; 2. rough data; 3. presentation; and 4. codification. The ASCII-signs-set with 7-bit-codification is the basis of Internet rough data and also of email. Data formats of the Semantic Web are in function because of Resource Description Framework (RDF), and enlarged in Web Ontology Language (OWI). The Entity-Relation-Modelling (ERM) makes it possible to visualize and to communicate how data are structured and represent formats in exchange (pp. 233-234). Protocols are complexes of rules for correct conduct. Digital protocols are fixing the behaviour of user roles in aim-directed cooperation and are specified in two parts: 1. process-order of communication steps (who with whom in which priority); and 2. included types of behavior and statements (what). A method for clear illustration of protocols is the diagram of sequence. Protocols are realized only by programmed protocol-machines inside the area of communication-machines oriented to the layers-model of the Internet. The Simple Mail Transfer Protocol (SMTP) defines the usual email-system of the Internet. HTTP organizes the access of browsers to documents of the web and constitutes the protocol basis of World Wide Web (WWW) (pp. 285-286).

\section{Medialization}

In communication studies or media studies, medialization (synonym with mediatization and mediation [Meyen, 2009, p. 24]) is a theory which argues that the media shape and frame the processes and discourse (conversation) of political communication as well as the society in which that communication takes place (Lilleker, 2008, p. 117). In this framework, an important aspect of modernization is the development of media (Krotz, 2008, pp. 37-41; Hepp, 2012, p. 1), beginning with a change in communication media and proceeding to subordination of the power of prevailing influential institutions (Hjarvard, 2008, p. 7). But mediatization theory does not provide until jet an actually unified conceptual framework for understanding contemporary media development (Finnemann, 2011, p. 79). As a consequence of this process, institutions and whole societies are shaped by and dependent on mass media (Mazzoleni \& Schulz, 1999, p. 247). Medialization is part of a paradigmatic shift in media and communication research. Following the concept of mediation, medialization has become the proper concept for capturing how processes of communication transform society, designating large-scale relationships. The two are complementary (Hepp, Hjavard, \& Lundby, 2015, p. 314). The concept has evolved to focus not only on media effects but also on the interrelation between the change of media communication on the one hand and socio-cultural changes on the other, as part of our everyday communication practices and our communicative construction of reality. Medialization is extended into everyday life, at work, at home and in between (Finnemann, 2011 p. 84). Currently, there is no actual general accepted definition of the subject within the scientific community. But the working-definition of Sarcinelli (1998, pp. 678-679) is very 
helpful. Medialization is defined by him (ibid) as 1. the increasing fusion of the reality of media; 2. growing perception of political \& social reality; and 3. orientation of political action and behaviour to the logics of the system of media (logics comp., Höltgen, 2018, formats, routines \& workflow, Meier, 2018, pp. 183-211; Redolf, 2017, pp. 88-92). Sarcinelli's working definition is helpful because medialization is figured there as process, multi-dimensional phenomena, reaction to the self-logic of media, multi-layers-phenomena, and allows possibilities of connections to, e.g., systems and action theory (Marcinkowski, 2015, p. 72). Medialization-research investigates the interrelation between media communicative change and socio-cultural change, understood as a meta-process (a conceptual construct designating long-term processes of change (Couldry \& Hepp, 2013, p. 191). Media do not cause the transformations necessarily but they have become co-constitutive for the articulation of politics, economics, education, religion, law (A. K.), etc. (Hepp et al., 2015, p. 314).

Hjarvard and Peterson (2013, p. 3) summarized media's role in cultural change:

(1) When various forms of subcultures try to make use of media for their own purposes, they often become (re-)embedded into mainstream culture; (2) National cultural policies often serve as levers for increased medialization; (3) Mediatization involves a transformation of the ways in which authority and expertise are performed and reputation is acquired and defended; and (4) Technological developments shape the media's affordances and thus the particular path of mediatization.

\section{Self-Medialization}

Self-mediatization of individual communicators is defined by their active, conscious, goal-directed orientation to the media including their logics, formats, genres, and working routines (esp. digital media see Herczeg, 2018) and workflow (Redolf, 2017, p. 102; analogous to Birkner, 2017, p. 70). The phenomenon of self-medialization of individual actors deals with active, conscious orientation on media or in other words: with no dysfunctional submission, but with conscious-specific control of media for appropriate-political and private aims. This phenomenon is to regard as something holistic in context with media, political communication, and cultural-socio-economical conditions. There are new starting points determined by the systems theories of political socialization and so on. Recommendations are to deduce from: to have a greater political distance and correction of political or critical media-competences. Prospectively, it does exist ample need on scientific research, because of several desiderata (e.g., in the non-public area), whereas there is hardly access for scientific research (Redolf, 2017, p. 109).

\section{Connections Between Digitalization and Medialization}

\section{Sociolinguistics}

Today sociolinguistics is facing the challenge of how to conceptualize the rapid expansion of its main object of study, socially meaningful linguistic differentiation, beyond the domain of spoken language in face-to-face interaction. This expansion is moving into two distinct, interrelated directions: 1. the rise of digitally mediated language as a new type of everyday language-in-use;and 2. the circuit of mediatized representation, uptake, and re-contextualization of linguistic fragments. Digitally mediated written language represents a historically new type of mediation. The sociolinguistic impact to digital mediation is more than its being a written representation of preexisting spoken-language variability and needs to understand how digital mediation expands the boundaries 
of visually constituted linguistic heterogeneity. The concept's medialization current predominant readings in linguistic anthropology and communication studies include the mediatized representation of sociolinguistic differentiation and its language-ideological implications, techniques of staging involved in these representations, and practices of uptake and circulation. Medialization and mediation help to open up the black-box notion of the media, in transgressing unproductive distinctions, such as the one between mass and new media, and to understand better media in terms of performance, staging, uptake, and re-contextualization (Androutsopoulos, 2016, pp. 282-283).

\section{Digitalization}

Digitalization can be interpreted as a complex interaction between a socio-cultural and digital-technological level (medialization). Concerning this interaction, there can be identified four technological push factors: 1 . datafication and digitalization; 2. networking and interaction; 3. sensorization and world surveying; and 4. algorithmization and machine-learning (Gapski, 2017, p. 1).

In the process of transformation, there are other social all-embracing sub-processes together with medialization, such as digitalization, individualization, globalization, and commercialization (Wimmer, 2017, p. 245). Medialization has an extreme dynamic performance, penetrates the society in nearly all areas but with different intensity and speed. This development is influenced technically by electronic media and especially by digitalization, networking, miniaturization, and portability of media. Digitalization does not mean only the technical transformation from analogue to digital information but also the holistic process of social change together with change of media environment. Medialization is also considered as a driver of digitalization (Hepp \& Pfadenhauer, 2014, p. 236).

So, digitalization is linked currently with medialization. Mediatization begins much earlier than medialization and thinking about phenomena of medialization (Averbeck-Lietz, 2016, p. 1). Nowadays medialization linked together with digitalization or in analogy, they are mutually dependent, because their contents and forms are interdependent. However, medialization cannot be thought respectively realized without juridification of media (Ziemann, 2018, pp. 67-68).

\section{Conclusion}

Small thesis-list at least: Concerning theoretical foundation digitalization, (self-) medialization and socialization by media and juridification have to be thought and understood together as complementary areas of research. Digitalization and standardization are influencing much the pragmatics, semiotics, and semantics of digital genres. (Self-) medialization of producers is influenced also very much by the pragmatics of digital genres. Digitalization and (self-) medialization are influencing very fundamentally the genesis of digital genres and formats. There have to be identified possibilities and cross section areas of connections between the task-force theories in a transdisciplinary conduct. Classical genre theory has to be actualized, modified, and adapted with these new theoretical constructs. By all means, there should be a fitting theoretical design and not an eclecticist mosaic of (possible) theories. Research-questions also in the research- field of legal discourses and genres have to be answered in the way of transdisciplinary empirical methods (Berr 2018a, pp. 4-9; 2018b, pp. 65-69). Also, aspects of transculturality (Herdin, 2018, pp. 60-71) have to be considered. There are naturally a lot of desiderata and therefore a lot of scientific work in future is expected. If these studies will be done well, the research-question 
concerning the influence of digitalization and medialization to legal discourse in relation to context, media, and social power can be answered better.

\section{References}

N. N. (2017). Postmediale kommunikationskulturen: Thesen zu phänomenen des digitalen wandels. Medien Journal, 41(1), 33-47.

Androutsopoulos, J. (2016). Theorizing media, mediation and mediatization. In N. Coupland (Ed.), Sociolinguistics: Theoretical debates (pp. 282-302). Cambridge: Cambridge University Press.

Averbeck-Lietz, S. (2016). Soziologie der kommunikation: Die mediatisierung der gesellschaft und die theoriebildung der klassiker. Retrieved from http://blog.mediatisiertewelten.de/2016/04/soziologie-der-kommunikation-die-mediatisierung-der-gesellschaft-und-die-theori ebildung-der-klassiker-ein-gastbeitrag-von-stefanie-averbeck-lietz/

Baetzgen, A. (Ed.). (2017). Brand design: Strategien für die digitale Welt. Stuttgart: Schäffer-Poeschel.

Berr, K. (Ed.). (2018a). Einführung. In Transdisziplinäre landschaftsforschung: Grundlagen und perspektiven (pp. 1-21). Wiesbaden: Springer \& Vieweg.

Berr, K. (Ed.). (2018b). Differenzierung und einheitsbildung in der landwirtschaftsforschung. In Transdisziplinäre landschaftsforschung: Grundlagen und perspektiven (pp. 41-77). Wiesbaden: Springer \& Vieweg.

Birkner, T. (2017). Medialisierung und mediatisierung. Baden-Baden: Nomos.

Blumler, J. G., \& Kavanagh, D. (1999). The third age of political communication: Influences and features. Political Communication, 16, 209-230.

Boehme-Neßler, V. (2008). Unscharfes recht: Überlegungen zu einer relativierung des rechts in der digitalisierten welt. Berlin: Duncker \& Humblot.

Bojanova, I. (2014). The digital revolution. What's on the horizon? IT Professional, 16(1), 8-12.

Couldry, N. (2012). Media society world: Social theory and digital media practice. Cambridge: Polity.

Couldry, N., \& Hepp, A. (2013). Conceptualizing mediatization: Contexts, traditions, arguments. Communication Theory, 23, 191-202.

Debjani, R. (2014). Cinema in the age of digital revolution. International Journal of Interdisciplinary and Multidisciplinary Studies, 1(4), 107-111.

Drescher, D. (2017). Blockchain grundlagen: Eine einführung in die elementaren konzepte in 25 schritten. Frechen: Mitp.

Finnemann, N. O. (2011). Mediatization theory and digital media. Communications, 36(1), 67-89.

Freeman, C., \& Louçã, F. (2002). As time goes by: From the industrial revolutions to the information revolution. New York, N.Y.: Oxford University Press.

Gapski, H. (2017). Big data als zeitenwende in gesellschaft, wissenschaft und politik und als herausforderung für die pädagogik. Retrieved http://www.bpb.de/lernen/digitale-bildung/medienpaedagogik/258197/big-data-als-zeitenwende-in-gesellschaft-wissenschaft -und-politik-und-als-herausforderung-fuer-die-paedagogik

Grimm, R., \& Delfmann, P. (2017). Digitale kommunikation: Sprache, protokolle und datenformate in offenen netzen. Berlin/Boston: de Gruyter \& Oldenbourg.

Hagen, L. M., \& Wieland, M., \& In der Au, A. M. (2017). Algoithmischer strukturwandel der öffentlichkeit: Wie die automatische Selektion im Social Web die politische Kommunikation verändert und welche Gefahren dies birgt. Medien Journal, 41(2), 127-143.

Hepp, A. (2012). Mediatization and the "molding force" of the media. Communications, 37(1), 1-28.

Hepp, A., \& Hjavard, S., \& Lundby, K. (2015). Medialization: Theorizing the interplay between media, culture and society. Media, Culture \& Society, 37(2), 314-324.

Hepp, A., \& Pfadenhauer, M. (2014). Medialisierte partizipation? Kleine formen der beteiligung jenseits von medienlogik. In F. Krotz, C. Despotović, and M. M. Kruse (Eds.), Die medialisierung sozialer welten: Synergien empirischer Forschung (pp. 235-262). Wiesbaden: Springer \& Vieweg.

Herczeg, M. (2018). Software-ergonomie: Theorien, modelle und kriterien für gebrauchstaugliche interaktive computersysteme. Berlin/Boston: De Gruyter \& Oldenbourg.

Herdin, T. (2018). Werte, kommunikation und kultur: Fokus China. Baden-Baden: Nomos.

Hierl, L. (Ed.). (2017). Mobile payment: Grundlagen-strategien-praxis. Wiesbaden: Springer \& Gabler. 
Hjavard, S. (2008). The mediatization of religion: A theory of the media as agents of religious change. Northern Light, 6(1), 9-26. Hjavard, S., \& Peterson, L. N. (2013). Mediatization and cultural change. Medie Kultur, 54, 1-7.

Höltgen, S. (Ed.). (2018). Medientechnisches wissen: Logik, informations-und speichertheorie. Berlin/Boston: De Gruyter \& Oldenbourg.

Jaekel, M. (2017). Die macht der digitalen plattformen: Wegweiser im zeitalter einer expandierenden digitalsphäre und künstlicher intelligenz. Wiesbaden: Springer \& Vieweg.

Keyling, T. (2017). Kollektives gatekeeping: Die herstellung von publizität in social media. Wiesbaden: Springer \& Vieweg.

Khan, S. (2016). Leadership in the digital age: A study on the effects of digitalization on top management leadership. Retrieved from https://su.diva-portal.org/smash/get/diva2:971518/FULLTEXT02.pdf

Koulu, R., \& Kallio, L., \& Hakkarainen, J. (2017). Law and digitalization: An agenda for the future. Retrieved from https://www.helsinki.fi/sites/default/files/atoms/files/ltl-report3.2.pdf

Krotz, F. (2007). Mediatisierung: Fallstudien zum wandel von kommunikation. Wiesbaden: Springer \& Vieweg.

Lehner, N. (2018). In gesellschaft von algorithmen: Geschichte, imaginäre und soziale Bedeutung algorithmisch vermittelter kommunikation. Wien: New Academic Press.

Lenzen, M. (2018). Künstliche intelligenz: Was sie kann \& was uns erwartet. München: Beck.

Lewrick, M. (2018). Design thinking: Radikale innovationen in einer digitalisierten welt. München: Beck.

Lilleker, D. G. (2008). Key concepts in political communications. London: Sage.

Lindenberg, B. M. (2018): Die zeichen stehen auf sturm: Gesellschaftliche veränderungen durch digitalisierung. In S. Vieweg, M. Müller-Wiegand, and H. Meisner (Eds.), Nachhaltige unternehmensführung in der digitalisierung: Instrumente-erfolgsfaktoren-praxisbeispiele (pp. 141-161). Berlin: Schmidt.

Lipp, T. (2015). TV-produzenten als denkmalpfleger-oder wer ist eigentlich für die mediale Erfassung des immateriellen Erbes zuständig? In C. Y. Robertson-von Trotha and R. H. Schneider (Eds.), Digitales kulturerbe: Bewahrung und zugänglichkeit in der wissenschaftlichen praxis (pp. 37-50). Karlsruhe: Scientific Publishing.

Livingstone, S. (2009): On the mediation of everything, ICA presidential address. Journal of Communication, 59(1), 1-8.

Lundby, K. (2009). Mediatization: Concept, changes, consequences. New York, N.Y.: Lang.

Marcinkowski, F. (2015). Die, Medialisierung von politik: Veränderte bedingungen politischer interessenvermittlung. In R. Speth and A. Zimmer (Eds.), Lobby work. interessenvertretung als politikgestaltung (pp. 71-95). Wiesbaden: Springer \& Vieweg.

Mazzoleni, G., \& Schulz, W. (1999). Mediatization of politics: A challenge for democracy? Political Communication, 16(3), 247-261.

McQuail, D. (2000). McQuail's mass communication theory. London: Sage.

Meier, J. (2018). Journalistik. Konstanz/München: UVK \& Lucius.

Meisner, H. (2017). Finanzwirtschaft in der internetökonomie. Wiesbaden: Springer \& Gabler.

Meyen, M. (2009). Medialisierung. Medien \& Kommunikationswissenschaft, 57(1), 23-38.

Oswald, G., \& Krcmar, H. (Eds.). (2018). Digitale transformation: Fallbeispiele und analysen. Wiesbaden: Springer \& Gabler.

Pispers, R., \& Rode, J., \& Fischer, B. (2018). Neuromarketing im Internet. Freiburg: Haufe.

Rauschnick, A. (2017). Big data, big divide? Zugang und repräsentation jenseits der filterblasen. Medien Journal, 41(3), 4-14.

Redolf, F. (2017). Zur theorie der selbst-medialisierung bei individuellen politischen akteurInnen. Zugl.: MT, Universitätslehrgang Communications MSc, Department \& Zentrum für Journalismus und Kommunikationsmanagement, Donau-Universität Krems.

Reichert, R. (Ed.). (2014). Big data: Zum digitalen wandel von wissen, markt und ökonomie. Bielefeld: Transcript.

Rid, T. (2018). Mythos cyberwar: Über digitale spionage, sabotage und andere gefahren. Hamburg: Edition Körber.

Sarcinelli, U. (1998). Mediatisierung. In O. Jarren, U. Sarcinelli, and U. Saxer (Eds), Politische kommunikation in der demokratischen gesellschaft: Ein handbuch mit lexikonteil (pp. 678-679). Opladen/Wiesbaden: Westdt. Verlag.

Schoenherr, S. E. (2004). The digital revolution. Retrieved from http://history.sandiego.edu/gen/recording/digital.html

Schröder, T. (2018). Medienkommunikation im wandel. In L. Blasch, D. Pfurtscheller, and D. Schröder (Eds.), Schneller, bunter, leichter? Kommunikationsstile im medialen wandel (pp. 13-34). Innsbruck: Innsbruck University Press.

Schumpeter, J. A. (1939). Business cycles: A theoretical, historical, and statistical analysis of the capitalist process. New York/London: McCraw-Hill.

Schüttpelz, E. (2017). Medienrevolutionen und andere revolutionen. ZFM, 2, 147-161.

Techtarget. (2014). Information age. Retrieved from http://searchcio.techtarget.com/definition/Information-Age 
Schwarzenegger, C. (2010). Rezension. In M. Hartmann, and A. Hepp (Eds.), Die mediatisierung der alltagswelt. Wiesbaden: Springer \& Vieweg.

Völz, H. (2017). Das ist information. Aachen: Shaker.

Walach, T. (2018). Geschichte des virtuellen denkens. Wiesbaden: Springer \& Vieweg.

Wimmer, J. (2017). Transformation durch mediatisierung und digitalisierung? Ergebnisse zum stellenwert sozialer netzwerkseiten und kommunikativer orientierung für politisches engagement. In U. Göttlich, L. Heinz, and M. R. Herbers (Eds.), Ko-orientierung in der medienrezeption: Praktiken der second screen-nutzung (pp. 245-265). Wiesbaden: Springer \& Vieweg. Wittgenstein, L. (1922). Tractatus logo-philosophicus. London: Kegan.

Wittgenstein, L. (1953). Philosophische untersuchungen. Frankfurt a, M.: Suhrkamp.

Ziemann, A. (2018). Medien und gesellschaft. In D. Hoffmann and R. Winter (Eds.), Mediensoziologie: Handbuch für wissenschaft und studium (pp. 86-99). Baden-Baden: Nomos. 